\title{
A Study of Porosity Effect on Tribological Behavior of Cast Al A380M and Sintered Al 6061 Alloys
}

\author{
Avijit Sinha, Zoheir Farhat \\ Department of Process Engineering and Applied Science, Materials Engineering Program, Dalhousie University, \\ Halifax, Canada \\ Email: avijit.sinha@dal.ca
}

Received 22 October 2014; revised 2 November 2014; accepted 19 December 2014

Copyright @ 2015 by authors and Scientific Research Publishing Inc.

This work is licensed under the Creative Commons Attribution International License (CC BY). http://creativecommons.org/licenses/by/4.0/

\section{Open Access}

\begin{abstract}
Due to their light weight, high corrosion resistance and good heat conductivity, aluminium alloys are used in many industries today. They are suitable for manufacturing many automotive components such as clutch housings. These alloys can be fabricated by powder metallurgy and casting methods, in which porosity is a common feature. The presence of pores is responsible for reducing their strength, ductility and wear resistance. The present study aims to establish an understanding of the tribological behavior of high pressure die cast Al A380M and powder metallurgy synthesized Al 6061. In this study, dry sliding wear behavior of Al A380M and Al 6061 alloys was investigated under low loads (1.5 $\mathrm{N}-5 \mathrm{~N}$ ) against AISI 52100 bearing steel ball using a reciprocating ball-on-flat configuration and frequency of $10 \mathrm{~Hz}$. Wear mechanisms were studied through microscopic examination of the wear tracks. This study revealed that due to combined effect of real area of contact and subsurface cracking, wear rate increased with increasing porosity content. The difference in friction and wear behavior between received $\mathrm{Al} \mathrm{A380M}$ and $\mathrm{Al} 6061$ is attributed to their hardness differences.
\end{abstract}

\section{Keywords}

Powder Metallurgy, Porosity, Hardness, Nanoindentation, Reciprocating Wear

\section{Introduction}

In automotive applications, aluminium is an attractive alternative to ferrous alloys due to its high strength to weight ratio and high thermal conductivity. The combination of light weight, high strength, good corrosion and 
impact resistance made aluminium alloys suitable candidates [1] [2]. However, low wear resistance compared to other materials (i.e. steels, ceramics), limits their use. The wear response of aluminium alloys significantly depends on their microstructure such as nature, size, shape and distribution of micro-constituents (porosity and second phase particles) [3]. Furthermore, it is well established that the microstructure of aluminium alloys depends on fabrication processes involved [4] [5].

High pressure die casting (HPDC) is a common method for producing aluminium parts. It is fully automatic, large volume, high productivity process for the production of complex, thin walled near net shape castings. Due to smooth surface finish and excellent dimensional tolerance, most high pressure die castings require no machining except the removal of flash around edges and possible drilling and tapping holes. More recently, near net shape processing of aluminium by classical press and sinter powder metallurgy has emerged as unique and important metal forming method [6]. Minimum metal loss, low energy consumption and ability to produce variety of alloy systems have made powder metallurgy attractive. In addition, uniform microstructure can be achieved through P/M. Powder metallurgy is used to produce complex automobile parts such as connecting rods, cams, roller bearings, cylinder liners, etc. [7]-[13].

However, a certain amount of porosity is common in both of these manufacturing techniques. The influence of porosity on the wear behavior is not clearly understood [14] [15]; it has been reported in some studies as beneficial and in others as detrimental. Chen et al. [16] investigated the influence of porosity on composite materials and they concluded that porosity could be beneficial to the performance of materials under some conditions. They suggest that, porosity may help absorb impact energy that accompanies crack splitting, which reduces crack propagation, and thus delays rapid fracture. A study conducted by Simchi and Danninger [17] showed a positive influence of porosity on wear behavior.

Commonly, the presence of pores has a detrimental effect on the wear performance of materials [18]-[30]. The potentially negative effect of porosity on the wear resistance is influenced by pore size, shape, distribution and density. Pores act as pre-existing incipient cracks in the subsurface layer, waiting to become unstable at an appropriate stress level [31]. Porosity is accompanied by a decrease in mechanical properties of materials such as strength and ductility [32]-[34]. For instance, Hardin and Beckermann [35] demonstrated an apparent reduction in elastic moduli of components due to the presence of pores. Experiments performed by Deshpande and Lin [36] reported that porosity in materials decreased their wear resistance due to the no-load bearing characteristics of pores on the wear surface. They also explained that depending on pore geometry and distribution, wear resistance vary and may promote severe wear. Suh [37] has found that an increase in porosity content reduces the required length of cracks needed to link up pores which promotes delamination. The effect of porosity on the wear and friction of metals has been studied by Vardavoulias et al. [38] and they suggested that the pores enhanced surface roughness of the materials, decreased the real area of contact between two sliding surfaces and consequently increased the contact pressure and promote particle detachment during sliding. Gui et al. [39] consider the pores as crack sources which can be created when an external force is applied. In general high porosity in materials leads to low strength and high wear rate [40].

Hence, a detailed understanding of the effect of porosity is necessary to assess wear properties of cast and $\mathrm{P} / \mathrm{M} \mathrm{Al}$ alloys. In this study, an attempt has been made to identify the relationship between surface porosity and wear behavior of aluminium alloys. In addition, wear behavior of different microstructures (due to different production methods) was investigated. A series of reciprocating wear tests were conducted under different loads and wear mechanisms were identified.

\section{Experimental Methods}

\subsection{Material Characterization}

High pressure die cast A380M aluminium clutch housing was obtained from Magna Powertrain and $6061 \mathrm{Al}$ powder was obtained from Ecka granules. Particle size analysis on the raw $6061 \mathrm{Al}$ powder was performed using Malvern particle size analyzer (model 2600c) equipped with MASTER particle sizer 3.1 analytical software. Here tests were conducted using a focal length of $100 \mathrm{~mm}$ and a beam length of $300 \mathrm{~mm}$. The average particle size of the $6061 \mathrm{Al}$ powder is $70.9 \mu \mathrm{m}$. The morphology of the powder is shown in Figure 1. The powder exhibits a somewhat spherical shape. The compositions of the Al 6061 powder and as received Al A380M alloy were determined using atomic absorption unit. The measured chemistries of Al 6061 powder and Al A380M alloy are summarized in Table 1. 


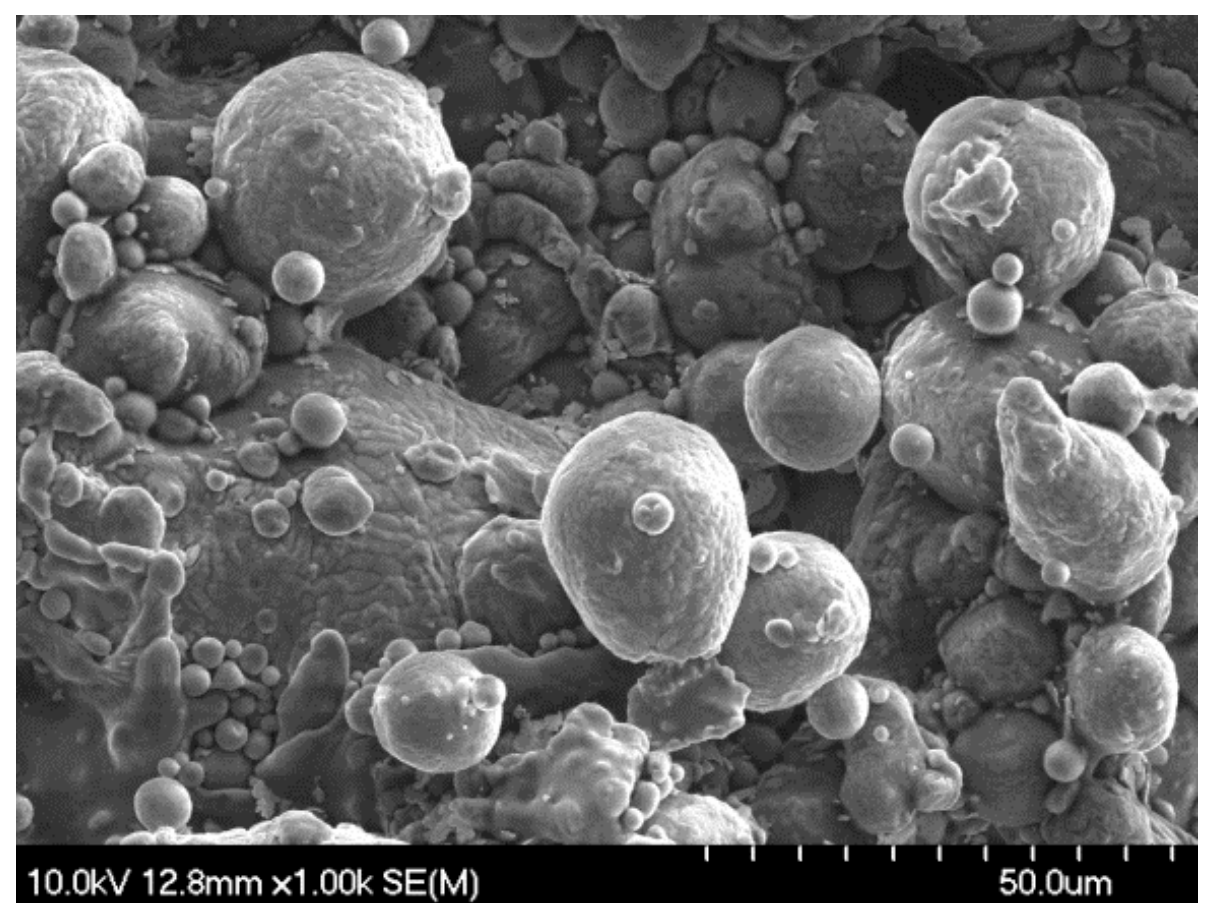

Figure 1. SEM image of Al 6061 powder.

Table 1. Chemical composition of Al A380 Malloy and Al 6061 powders.

\begin{tabular}{cccccccc}
\hline Elements (\%) & Al & Mg & Si & Fe & Cu & Zn & Mn \\
\hline Al 6061 & 97.5 & 1 & 0.6 & 0.5 & 0.1 & 0.2 & 0.1 \\
Al A380M & 85.2 & 0.07 & 8.35 & 0.06 & 0.05 & 0.75 & 2.15 \\
\hline
\end{tabular}

\subsection{Materials Preparation}

The 6061 Al powder was weighed using a Denver Instruments APX-1502 scale and placed in Nalgene bottles. A total of $0 \%$ and $1.5 \%$ lubricant (Lico wax C) was added to the powder and blended in a Turbula Model T2M mixer for 40 minutes to ensure homogeneity. Rubber molds were filled with the blended powders and sealed with electrical tape. The sealed molds were then transferred to a cold isostatic press (CIP) chamber for wet bag pressing. The chamber was filled with a mixture of water and water soluble oil (20:1). Using a high pressure airoperated piston type pump, the pressure within the pressure chamber was increased to $200 \mathrm{MPa}$ and maintained for a dwell time of 5 minutes. The pressure was then released and the compacts were removed. To increase density, green compacts were subsequently sintered in a Linderburg Blue 3-Zone Tube Furnace Model STF 55666C-1. Once the samples were placed in the furnace the pressure in the tube was reduced to a value less than $9.9 \times 10^{-2}$ Torr and then backfilled with nitrogen. This was repeated to minimize oxygen contamination in the atmosphere. Nitrogen was then allowed to flow continuously at a rate of $9.4 \mathrm{~L} / \mathrm{min}$. Heating of samples progressed in three stages: de-lubrication, sintering and post-sintering cooling. After ensuring that all the oxygen had been evacuated and that the nitrogen was flowing properly, the temperature was quickly ramped to $400^{\circ} \mathrm{C}$ and held for 20 minutes. After the 20 minutes dewax stage, the furnace was then ramped to the final sintering temperature of $620^{\circ} \mathrm{C}$ and held for a time period of 30 minutes. The power to the furnace was then turned off and the samples allowed to cool to $580^{\circ} \mathrm{C}$.

The green and sintered densities of samples were determined in accordance with MPIF standard 42. In order to determine the unsintered (green) density, samples were weighed in air ( $\left.W_{\text {air }}\right)$ and the water temperature was recorded. The green density was calculated using $\rho_{\text {Green }}=W_{\text {air }} \rho_{\text {water }} /\left(W_{\text {air }}-W_{\text {water }}\right)$, where $\rho_{\text {water }}$ is the density of water calculated using, $\rho_{\text {water }}=7 \times 10^{-8} T^{3}-1 \times 10^{-4} T+0.9996$, where $T$ is the measured temperature of the water in degree Celsius. The sintered density was measured by weighing the samples in air ( $W_{\text {air }}$ ), prior to infil- 
trating them with ESSO-NUTO H46 hydraulic oil, then weighing the samples in air (with oil impregnation). Oil impregnated samples were then weighed in water and the sintered density was calculated as follows:

$\rho_{\text {sintered }}=W_{\text {air }} \rho_{\text {water }} /\left(w_{a o}-w_{w o}\right)$, where $w_{w o}$ the weight of the oil is infiltrated specimen in air and $w_{w o}$ is the weight of the oil infiltrated specimen in water. The green and sintered density values of the samples are given in Table 2. The volume percentage of porosity (Table 2) is calculated using $100-\left(\frac{\text { sintered density }}{\text { theoritical density }} \times 100\right)$,

where the theoretical density of $\mathrm{Al} 6061$ is $2.70 \mathrm{~g} / \mathrm{cc}$.

HPDC A380M Al and sintered $6061 \mathrm{Al}$ specimens were prepared for metallographic examination using 240, 320, 400 and $600 \mathrm{SiC}$ abrasive papers and 0.1, 0.3 and 0.05 alumina suspensions for polishing. Olympus BX51 microscope, equipped with bright field objectives was used to analyze the specimens at high resolution. Surface porosities of samples were calculated using image analysis software. A series of images were taken to cover the whole surface area of the sample. Porosity was identified based on their gray-level intensity differences compared to the matrix. Gray-level threshold settings were selected to permit independent detection of porosity, using the "flicker method" of switching back and forth between porosity and the matrix. Second phase particles and dendrites may be counted as porosity because their gray-level range is similar to that of porosity. The gray-level thresholds as well as boundary conditions (i.e., aspect ratio, minimum radius and area) were set to avoid second phase particles and dendrites detection. A counting protocol was chosen to correct for edge effects so that a porosity lying across a field boundary is counted only once. For each field the area fraction of porosity was calculated by dividing the area of covered by porosity by the total field area.

\subsection{Wear Testing}

Dry reciprocating wear tests were performed using a Universal Micro-Tribometer. This test method utilizes a ball upper specimen that slides against a flat lower specimen in a linear, back and forth sliding motion having a stroke length of $5.03 \mathrm{~mm}$. All tests were conducted at room temperature and at a relative humidity of $40 \%-55 \%$. The load is applied downward through the ball counter-face against a flat specimen mounted on a reciprocating drive. The tester allows for monitoring the dynamic normal load and friction force during the test. A $6.3 \mathrm{~mm}$ diameter AISI 52100 bearing steel ball with a hardness of HRA 83 was used as a counter-face material. The ball was mounted inside a ball holder, which is attached directly to a suspension system. The suspension system is attached to a load sensor that controls and records forces during the test. The weight of the specimen was measured before and after each wear test to determine individual weight loss at selected time intervals. Six different loads (1.5, 2, 2.5, 3, 4, $5 \mathrm{~N}$ ) were employed; each tested under $10 \mathrm{~Hz}$ frequency and for 120 minutes. After wear tests, worn surfaces of wear tracks were examined using optical profilometry to calculate the volume loss. Image analysis software calculates volume loss from the differences between the interpolated reference plane and the actual worn surface. Scanning electron microscope was used to determine possible wear mechanisms.

\subsection{Rockwell Hardness and Nanoindentation}

Rockwell hardness tests were carried out in all $\mathrm{Al}$ A380M and $\mathrm{Al} 6061$ specimens. Tests were performed on a Leco R600 Rockwell hardness tester using the " $\mathrm{H}$ " scale under a load of $60 \mathrm{~kg}$ and a diamond indenter. Nanoindentation experiments were conducted using a nanoindentation system (developed by CETR, USA). The instrument uses a Berkovich diamond pyramid with an angle of $65.3^{\circ}$ between the tip axis and the faces of the triangular pyramid. The total penetration depth consists of a plastic component and an elastic recovery component which occurs during the unloading. Maximum indentation depth $\left(h_{\max }\right)$ can be expressed as:

$$
h_{\max }=h_{c}+\left[\frac{(\pi-2)}{\pi}\right]\left(\frac{2 P_{\max }}{\mathrm{d} p / \mathrm{d} x}\right)
$$

Table 2. Basic properties of sintered Al 6061.

\begin{tabular}{cccc}
\hline Al $\mathbf{6 0 6 1}$ & Green density (g/cc) & Sintered density (g/cc) & Volume porosity (\%) \\
\hline No Wax & 2.49 & 2.52 & 6.5 \\
1.5\% Wax & 2.24 & 2.32 & 13.8 \\
\hline
\end{tabular}


where $p$ and $h$ are load and indentation depth, respectively. $h_{\max }, P_{\max }$ and slope at maximum load $\mathrm{d} p / \mathrm{d} h$ are determined from the load versus displacement profile. The relationship between hardness $H$ and the maximum applied load $\left(P_{\max }\right)$ is as follows:

$$
H=\frac{P_{\max }}{A}
$$

where $A$ is the area of contact for Berkovich indenter and is given by,

$$
A=24.5 h_{c}^{2}
$$

where $h_{c}$ is the contact depth. The elastic modulus can be expressed as

$$
E^{*}=\frac{1}{2} \frac{\mathrm{d} p}{\mathrm{~d} h} \frac{\sqrt{\pi}}{\sqrt{A}}
$$

where

$$
\frac{1}{E^{*}}=\frac{1-v_{1}^{2}}{E_{1}}+\frac{1-v_{2}^{2}}{E_{2}}
$$

here, $E_{2}$ and $V_{2}$ are elastic modulus and Poisson's ratio of the test material respectively, and $E_{1}$ and $V_{1}$ are the same parameters for Berkovich indenter.

\section{Results and Discussion}

\subsection{Microstructure and Surface Morphology}

The size, shape and amount of pores in compacts are largely dependent on processing parameters like the amount of lubricant used and compaction pressure. Different surface characteristics were observed with and without adding wax. For $\mathrm{Al} 6061$ specimens, surface porosity ranges from 3.5\% for no wax to $10.3 \%$ for $1.5 \%$ wax (Table 3). Figure 2(a) \& Figure 2(b) represents the variation of the microstructures of these two specimens. As the specimens were compacted under the same pressure and sintered under the same sintering conditions, the amount of lubricant plays the most significant role in determining pore size, shape and amount. The added lubricant flows between $\mathrm{Al}$ particles and impede pore closure during compaction. Pores that were present in the compact contained lubricant. During sintering, the lubricant is burned off leaving behind pores in the material.

Porosity in high pressure die cast aluminium component is caused by the combined effects of solidification shrinkage and gas entrapment. Shrinkage takes place when the metal is solidifying inside the die. This shrinkage may form voids, known as shrinkage porosity. Gas porosity is caused by the entrapment of air during the casting process. Shrinkage porosity tend to be large and irregular in shape while gas porosity is small and spherical in shape. The as received high pressure die cast $\mathrm{Al} \mathrm{A380M}$ alloy exhibits $0.6 \%$ gas porosity and $1.5 \%$ shrinkage porosity. These two types of porosity are combined to give the final porosity content of $2.1 \%$.

It is noticeable from Table 3 that, there is no difference in $\mathrm{Al}$ grain size for sintered $6061 \mathrm{Al}$ specimens, i.e., the presence of wax does not effect the grain size of sintered $6061 \mathrm{Al}$. This behavior is expected since compaction pressure and sintering protocol is the same for all specimens. The shape and distribution of pores were also similar in all samples. However, the size of the pores and amount of surface porosity increased from $12 \mu \mathrm{m}$ and

\begin{tabular}{|c|c|c|c|c|c|}
\hline Specimen & $\begin{array}{c}\text { Al grain } \\
\text { size }(\mu \mathrm{m})\end{array}$ & $\begin{array}{c}\text { Pore size } \\
(\mu \mathrm{m})\end{array}$ & Pore shape & $\begin{array}{c}\text { Surface } \\
\text { Porosity (\%) }\end{array}$ & Pore distribution \\
\hline $\begin{array}{c}\text { Al } 6061 \\
\text { (No wax) }\end{array}$ & 45 & 12 & Round & 3.5 & Uniform \\
\hline $\begin{array}{c}\text { Al } 6061 \\
\text { (1.5\% wax) }\end{array}$ & 45 & 20 & Round & 10.3 & Uniform \\
\hline Al A380M & 25 & 31 & Irregular & 2.1 & Non-uniform \\
\hline
\end{tabular}
$3.5 \%$ to about $20 \mu \mathrm{m}$ and $10.3 \%$, as the amount of wax increased from 0 to $1.5 \%$ wax, respectively. The average pore size of the high pressure die cast $\mathrm{A} 380 \mathrm{M} \mathrm{Al}$ is significantly larger than those of sintered $6061 \mathrm{Al}$ alloy, but

Table 3. Microstructural characteristics of A380M Al and $6061 \mathrm{Al}$. 

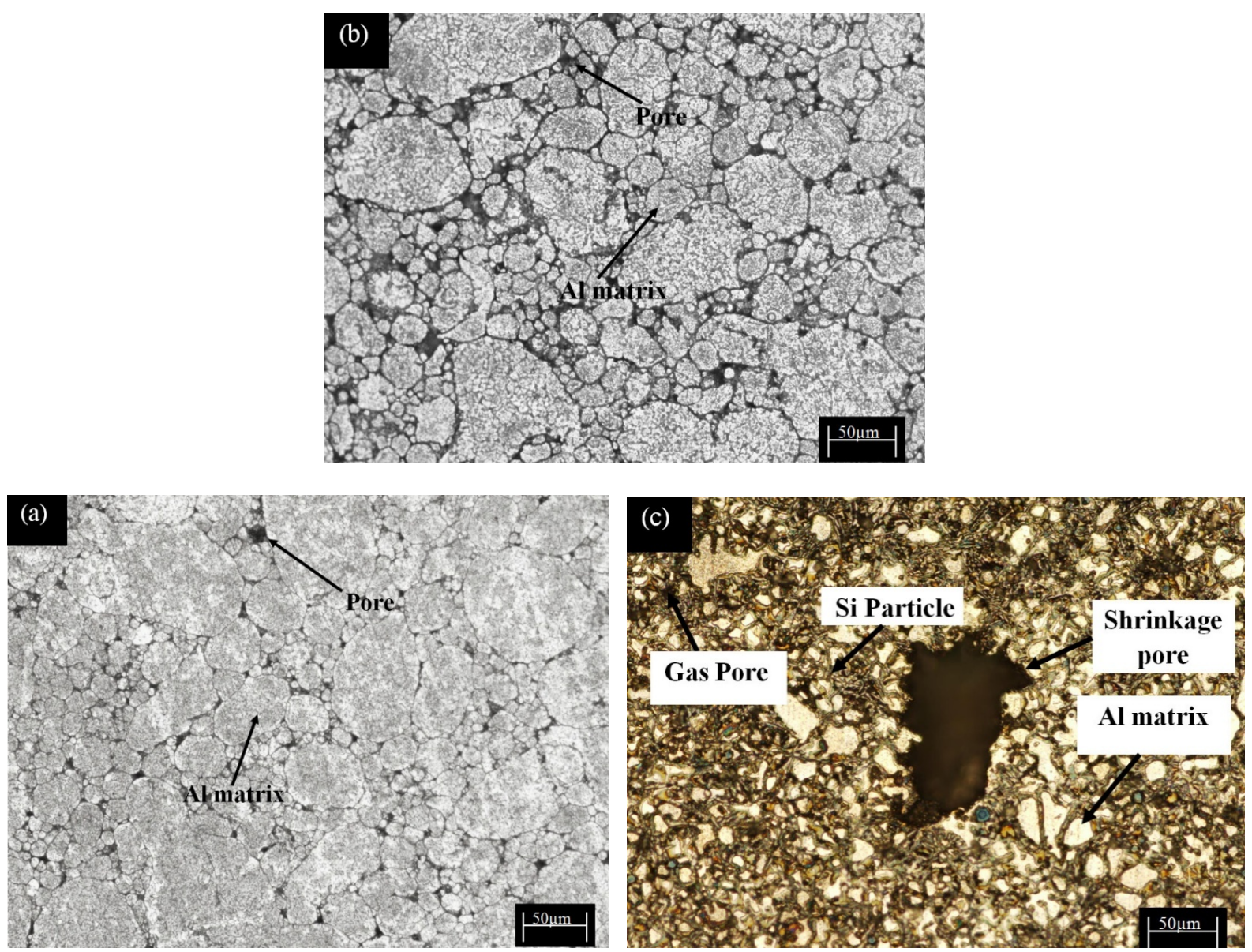

Figure 2. Optical micrographs of (a) sintered $6061 \mathrm{Al}$ without wax (b) sintered $6061 \mathrm{Al}$ prepared using 1.5\% wax (c) HPDC A380M Al.

the amount of porosity is lower and non-uniformly distributed.

\subsection{Factors Effecting Hardness}

To investigate the possible factors effecting the hardness of $\mathrm{A380M} \mathrm{Al}$ and $6061 \mathrm{Al}$, a series of Rockwell hardness measurements were conducted and plotted in Figure 3. This curve shows a gradual decrease in hardness with increasing porosity. There is a reduction in hardness of about $20 \%$ as porosity increases from $3.5 \%$ to 10.3\% for Al 6061 specimens. The decrease in hardness with increase in porosity is a result of the decrease in the effective load-bearing area. The high hardness exhibited by HPDC A380M Al may be contributed to both lower amount of porosity and higher Si content.

Furthermore, nanoindentation tests were performed on all Al specimens and nanohardness and Young's modulus were calculated using Oliver and Pherr method [41]. Figure 4 shows typical load-depth curves obtained from nanoindentation experiments for $\mathrm{A} 380 \mathrm{M}$ and $6061 \mathrm{Al}$ alloys. The influence of porosity on Young's modulus and nanohardness of the specimens is given in Table 4. From this table, it is clear that, Young's modulus and nanohardness values are higher in A380M alloy than in $\mathrm{Al} \mathrm{6061.} \mathrm{A} \mathrm{reduction} \mathrm{of} \mathrm{about} 10 \%$ in Young's modulus and $4 \%$ in nanohardness is observed when the surface porosity increased from $3.5 \%$ to $10.3 \%$ in $6061 \mathrm{Al}$, respectively. The morphology of the pores immediately beneath the surface or within the zone of influence has a significant effect on the response of the indenter and the measured nanohardness and Young's modulus. The resistance that the indenter experience, as it becomes in contact with a solid phase in the Al specimen, depends on whether or not pores are present beneath the surface. As the amount of porosity increases, the resistance to deformation drops. Similarly, the maximum depth $\left(h_{\max }\right)$ of penetration of the indenter, for given maximum load, increases with the amount of porosity. From the load-depth curve, it is observed that, at a 


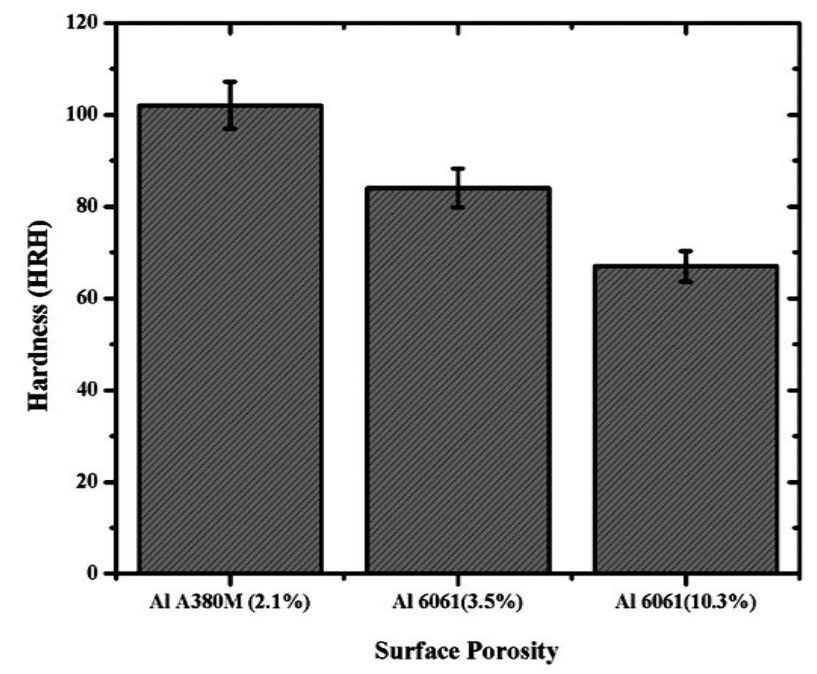

Figure 3. Variation in hardness with surface porosity for $\mathrm{A} 380 \mathrm{M} \mathrm{Al}$ and 6061Al.

Table 4. Nanoindentation test data.

\begin{tabular}{ccc}
\hline Specimen & Young's modulus (GPa) & Hardness (GPa) \\
\hline Al 6061 (3.5\% porosity) & 57 & 0.67 \\
Al 6061 (10.3\% porosity) & 51 & 0.64 \\
Al A380M (2.1\% porosity) & 69 & 1.00 \\
\hline
\end{tabular}

constant max load of $100 \mathrm{mN}$, A380M Al curve shows a max depth of $2.1 \mu \mathrm{m}$ while $6061 \mathrm{Al}$ having $3.5 \%$ and $10.3 \%$ porosity show max depths of 2.7 and $3.0 \mu \mathrm{m}$ respectively. For the 6061 alloy, the increase in the max depth with porosity is consistent with the above argument. As outlined in the experimental section, there is an inverse relationship between contact depth $\left(h_{c}\right)$ and nanohardness and Young's modulus. Furthermore, the relationship between maximum indentation depth $\left(h_{\max }\right)$ and the contact depth $\left(h_{c}\right)$ is given by the following equation:

$$
h_{\max }=h_{c}+\frac{\pi-2}{\pi} h_{e}
$$

where, $h_{e}$ is the elastic depth upon unloading. The observed increase in $h_{\max }$ with increasing porosity in $6061 \mathrm{Al}$ is accompanied by a corresponding increase in $h_{c}$. Thus, it can be concluded from this argument that, as the contact depth increases, contact area $\left(A=24.5 h_{c}^{2}\right)$ also increases and accordingly nanohardness and Young's modulus decrease. Fleck et al. [42] studied the effect of porosity on indentation using both finite element analysis and cavity expansion model. They suggested that, resistance to indentation decreases with increasing porosity. Similar conclusion has been reached by others [43]-[45] regarding the relationship between nanohardness, Young's modulus and porosity.

\subsection{Effect of Porosity on Wear Rate}

Figure 5 represents the correlation between weight loss and sliding distance for $\mathrm{Al} \mathrm{A380M}$ and $\mathrm{Al} 6061$ (3.5\% porosity). Similar trend is also obtained in Al 6061 (10.3\% porosity). The plots reveal a somewhat linear increase in weight loss with sliding distance. It is observed that at any given sliding distance, weight loss increases with applied load as is evident by the upward shift in the weight loss versus sliding distance curve. This trend is in agreement with other researchers [46]-[58]. To investigate the effect of porosity on wear resistance, wear rate, calculated as the slope of the weight loss versus sliding distance, is plotted as a function of normal load. The wear rates of $\mathrm{Al} \mathrm{A380M}$ containing 2.1\% surface porosity and $\mathrm{Al} 6061$ containing 3.5\%, 10.3\% surface porosity 


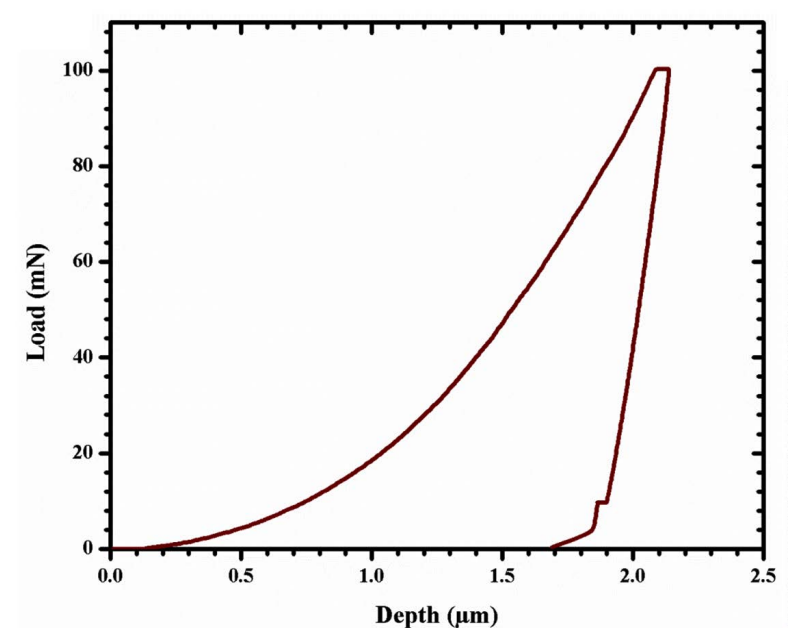

(a)

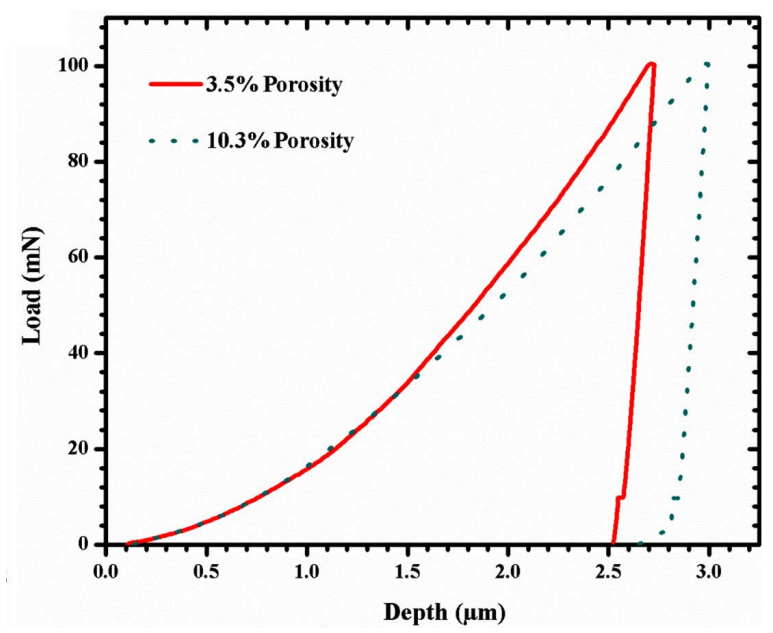

(b)

Figure 4. Load vs depth profile for (a) A380M Al and (b) $6061 \mathrm{Al}$ using a max load of $100 \mathrm{mN}$.

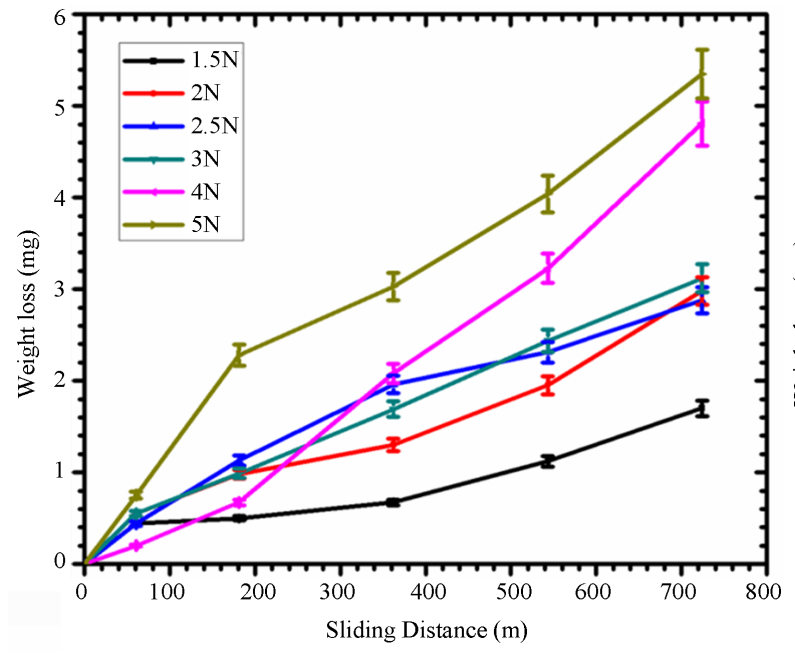

(a)

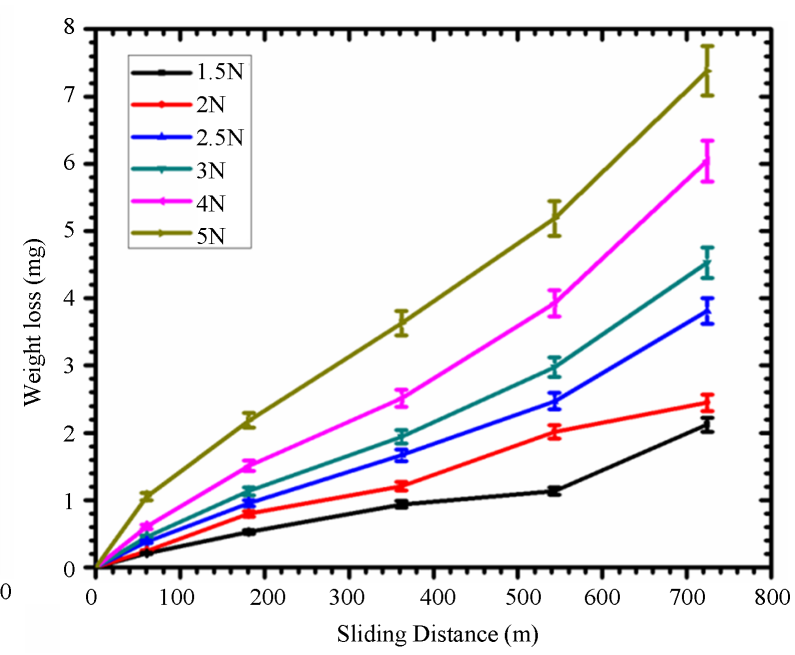

(b)

Figure 5. Weight loss versus sliding distance curve for (a) Al A380M and (b) Al 6061 (3.5\% porosity).

are plotted in Figure 6. It is clearly evident that, under the same loading condition, wear rate of $\mathrm{Al} 6061$ is higher than $\mathrm{Al} \mathrm{A380M.} \mathrm{It} \mathrm{is} \mathrm{also} \mathrm{noted} \mathrm{from} \mathrm{Figure} 6$ that, the difference in wear rate between $\mathrm{Al} A 380 \mathrm{M}$ and Al 6061 is low for low applied loads $(1.5 \mathrm{~N})$ and increases at higher load $(5 \mathrm{~N})$.

The stress intensity is particularly high near pores which act as sources for cracks during wear. The stress intensity increases with increasing normal load. At low load, the pores beneath the worn surface remain stable and can not propagate significantly. As a result, subsurface deformation and strain are relatively low. However, with increasing load, pores beneath the worn surface become unstable and cracks originated from these pores can propagate significantly. Consequently, areas surrounding pores become failure-prone.

The effect of porosity on wear resistance depends not only on total porosity content, but also on pore distribution and connectivity. When the pores are uniformly distributed, cracks can propagate at high rate as pores can easily link up with each other and forming a wide network of cracks. This effect ultimately contributes to the fracturing of material and increasing wear rate. Pores in $6061 \mathrm{Al}$ are more uniformly distributed than $\mathrm{A} 380 \mathrm{M} \mathrm{Al}$ (see Figure 2), which may also contribute to the higher wear resistance exhibited by A380M Al. Al 6061, wear rate increased about $30 \%$ as the surface porosity increased from 3.5\% to $10.3 \%$. Similar results (increase in wear 
rate with increasing porosity) were reported by other researchers [59] [60]. Furthermore, with increase in the amount of porosity, the link up of pores and the distance cracks need to travel before meeting another pore is shorter, thus, increasing fracturing and wear. Figure 7 is a schematic diagram showing the effect of pore distribution on wear rate.

\subsection{Load and Porosity Effects on Coefficient of Friction}

The coefficient of friction is plotted as a function of load in Figure 8. From this figure, it is observed that the coefficient of friction decreases considerably with increasing load but increases with increasing porosity content. For HPDCAL A380M alloy, the coefficient of friction decreases about $36 \%$ as the applied normal load increases from $1.5 \mathrm{~N}$ to $5 \mathrm{~N}$. Under dry sliding conditions, the generation of frictional heat between two sliding surfaces raises the temperature at the interface [61] [62]. This temperature rise promotes softening of the aluminium, which in turn, lowers the coefficient of friction with increasing load.

For Al 6061 alloy, at a given normal load of $3 \mathrm{~N}$, the coefficient of friction increases $40 \%$ when surface porosity increases from $3.5 \%$ to $10.3 \%$. In porous surface, the probability of generating wear debris increases as a consequence of increased asperity-asperity contact. Therefore, the rise in coefficient of friction with increasing porosity might be attributed to the formation of more asperity-asperity contact during sliding. Yalcin [63] also

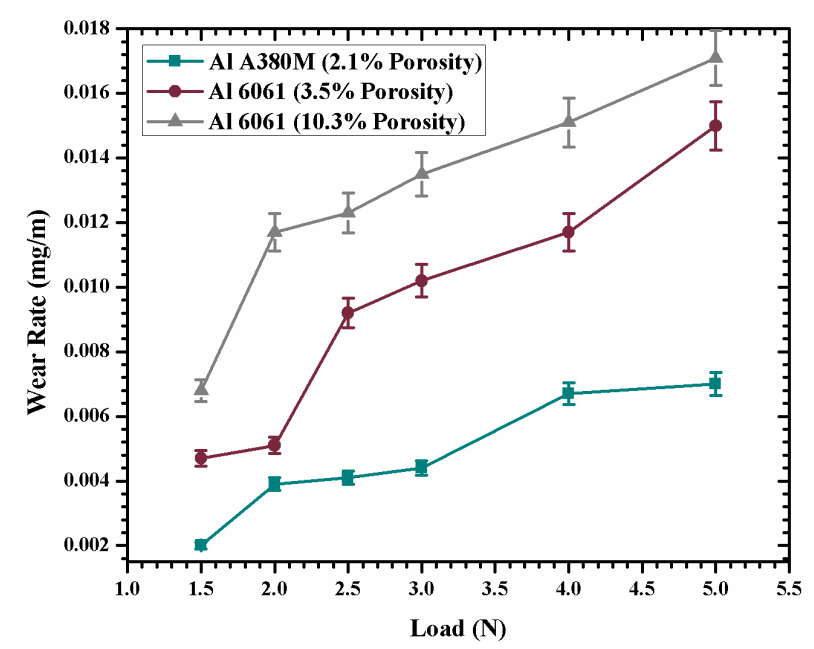

Figure 6. Wear rate versus normal load as a function of porosity at $10 \mathrm{~Hz}$ frequency.

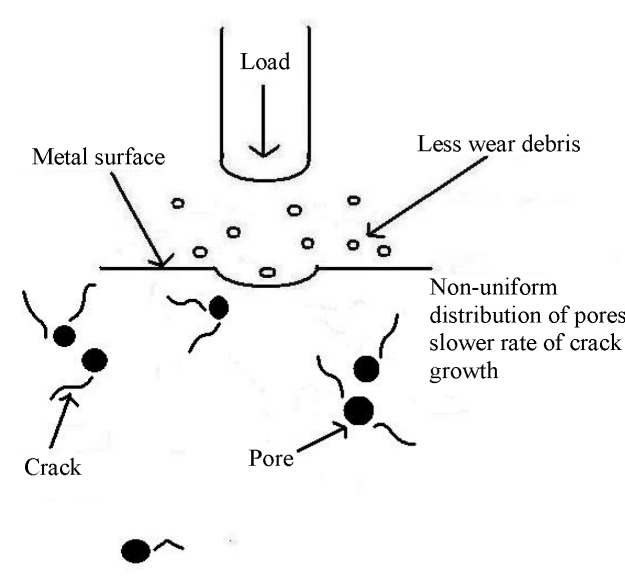

(a)

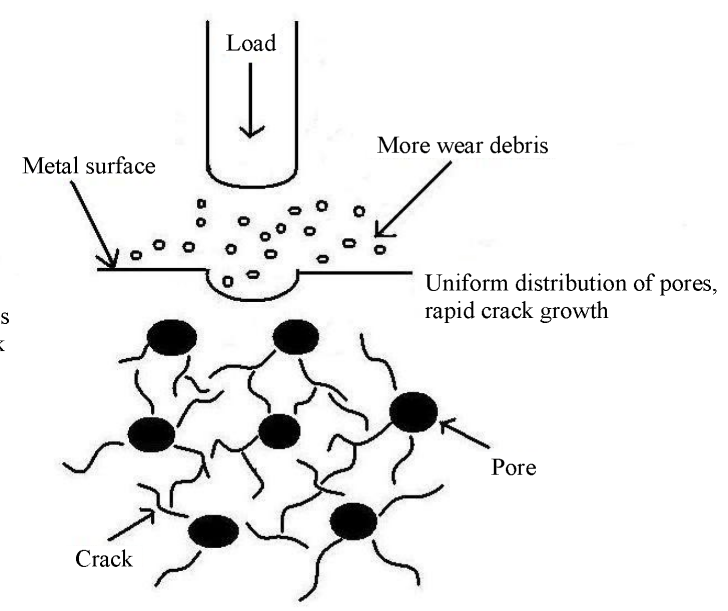

(b)

Figure 7. Schematic diagram depicting the effect of (a) non-uniform and (b) uniform pore distribution on wear rate. 


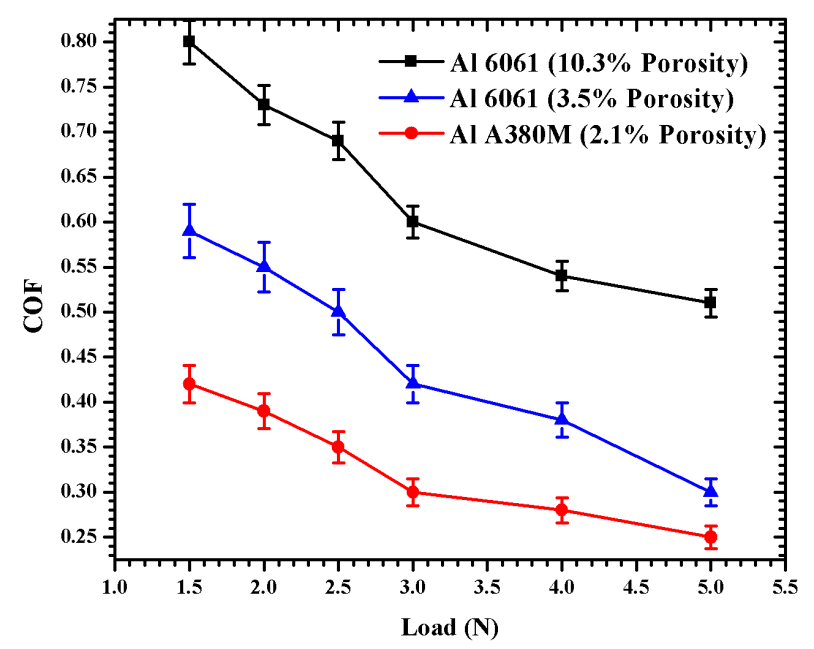

Figure 8. Coefficient of friction vs load as a function of porosity at $10 \mathrm{~Hz}$ frequency.

found similar results (increase in coefficient of friction with increasing porosity). He further suggested that, under dry friction conditions, an increase in the coefficient of friction results in an increase in the mass loss of the porous material.

\subsection{Worn Surface Evolution}

Worn surfaces of $\mathrm{Al} \mathrm{A380M}$ and $\mathrm{Al} 6061$ specimens were analyzed using optical profilometer and scanning electron microscope. Figure 9 represents optical profilometry scans of wear tracks of both $\mathrm{Al} \mathrm{A} 380 \mathrm{M}$ and $\mathrm{Al}$ 6061 at 3, 4 and $5 \mathrm{~N}$ load (starting from the left) and $10 \mathrm{~Hz}$ frequency. It is important to underline here that the depth of the wear tracks varied significantly in each sample with increasing load. Due to low weight loss in $\mathrm{Al}$ A380M in comparison to $\mathrm{Al} 6061$, wear track depths were shallower than those of $\mathrm{Al} 6061$ specimens. At $5 \mathrm{~N}$ load and $10 \mathrm{~Hz}$ frequency, the wear track depth of $\mathrm{Al} \mathrm{A380M}$ is 48 and 55\% lower than those for $\mathrm{Al} 6061$ having $3.5 \%$ and $10.5 \%$ porosity, respectively.

The variation in volume loss with applied normal load (calculated from profilometry scans in Figure 9) is plotted in Figure 10. The curve shows a somewhat linear relation between normal load and volume loss for a given porosity level. The volume loss increased with increasing porosity as expected. As discussed earlier wear resistance increases as hardness increases. At low load $(1.5 \mathrm{~N})$ the volume loss increases by $42 \%$ as porosity increases from $3.5 \%$ to $10.3 \%$. However, at high load $(5 \mathrm{~N})$ the difference in percent volume loss (46\%) is over 2 times higher than low load.

Scanning electron microscopy images of worn surfaces were examined to identify possible wear mechanisms. Figure 11 and Figure 12 show wear surface morphologies of $\mathrm{Al} \mathrm{A380M}$ and $\mathrm{Al} 6061$ specimens containing 2.1\% and $10.3 \%$ porosity, respectively, under $2.5 \mathrm{~N}$ load and $10 \mathrm{~Hz}$ frequency. Two wear mechanisms have been identified from SEM as dominant mechanisms during dry sliding wear of $\mathrm{Al} \mathrm{A} 380 \mathrm{M}$ aluminium alloy, namely, abrasion and delamination. Abrasion plays a significant role in the process as depicted by the shallow grooves along the wear track (Figure 11(a)). These grooves extend parallel to the sliding direction. Such features are characteristics of abrasion, in which hard asperities of the steel counterface plough through the Al specimens.

A second mechanism contributing to the observed wear is delamination. Plastic deformation leads to changes in the microstructure of the subsurface, making the material unstable to local shearing causing delamination [64]. Delamination wear occurs as a result of subsurface nucleation of cracks at pores and propagation of these cracks. Pores serve as the origin and end of crack propagation, hence reducing the required length of crack propagation. Figure 11(b) shows evidence of delamination as a result of plastic deformation of the surface. Hertzian-type cracks were also observed on the worn surface as a result of surface tensile stresses that evolve during Hertzian contact (Figure 1(c)). These types of cracks normally extend perpendicular to the sliding direction.

EDS analysis was conducted on the worn surface of Al A380M alloy and is shown in Figure 11(d). EDS confirmed that, the worn surface contained a considerable amount of oxygen. The presence of oxygen on the 

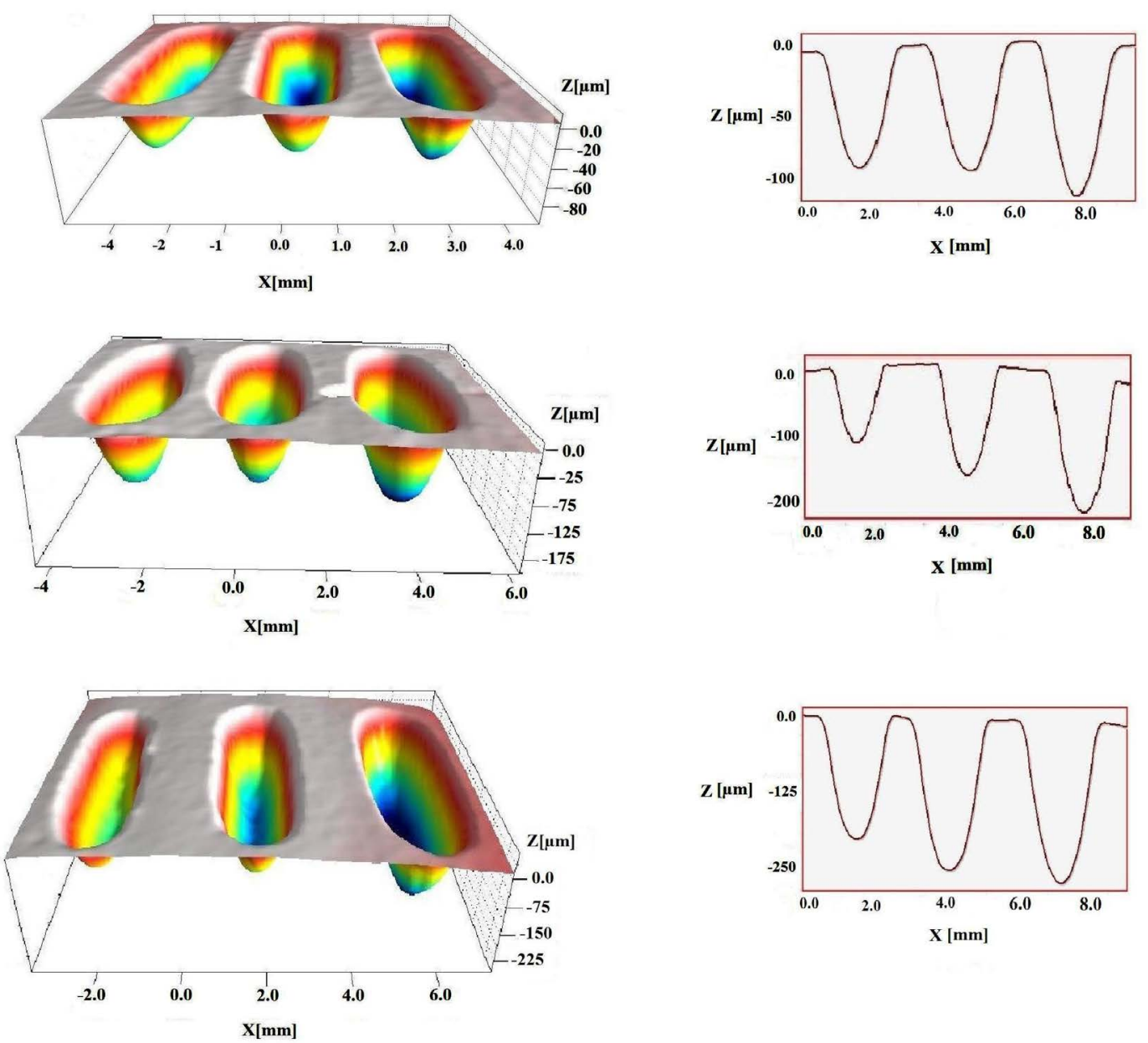

Figure 9. Optical profilometry scans of wear tracks. (a) (b) Al A380M; (c) (d) Al 6061 (3.5\% porosity) and (e) (f) Al 6061 (10.3\% porosity) at 3,4 and $5 \mathrm{~N}$ load and $10 \mathrm{~Hz}$ frequency.

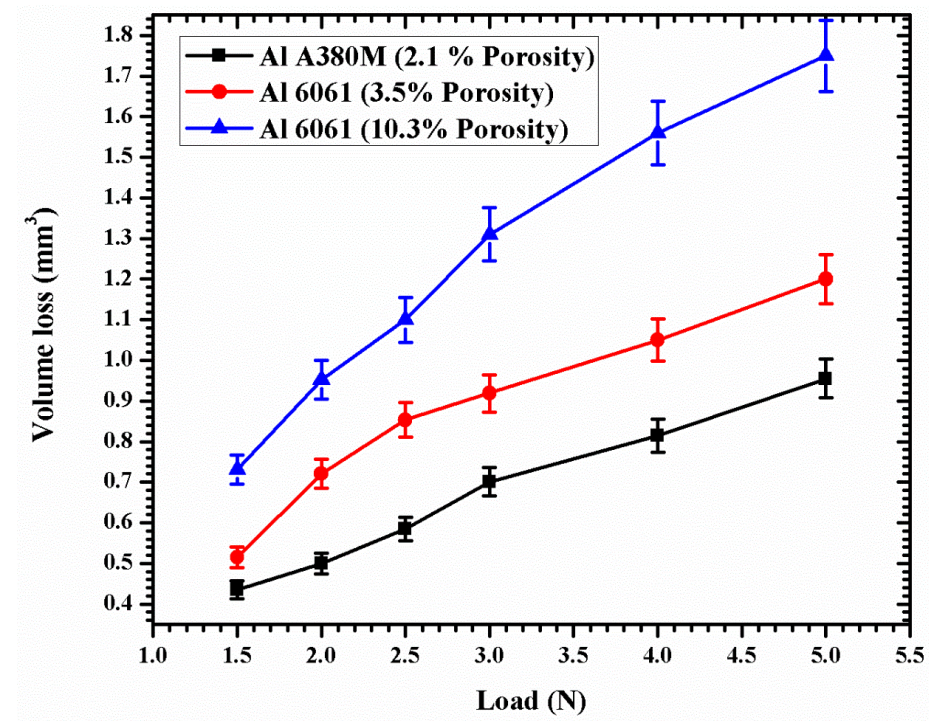

Figure 10. Variation in volume loss as a function of applied load for Al 6061 and A380M alloy at $10 \mathrm{~Hz}$ frequency. 

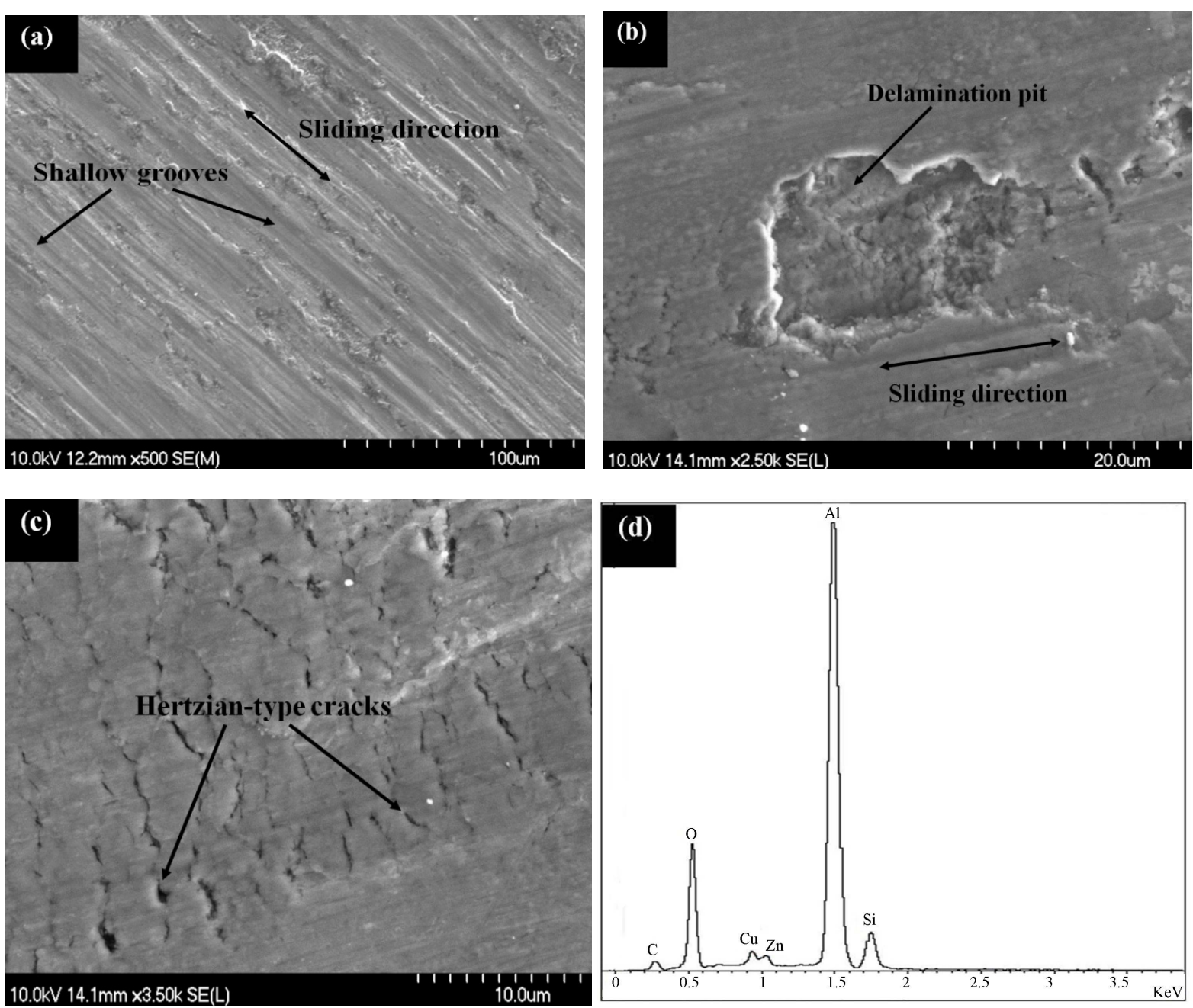

Figure 11. SEM micrographs of $\mathrm{Al} \mathrm{A380M}$ wear track at $2.5 \mathrm{~N}$ load and $10 \mathrm{~Hz}$. (a) Shallow grooves on the wear track; (b) Delamination pit; (c) Hertzian type cracks on the worn surface; (d) EDS analysis of the worn surface.

worn surface is indicative of oxidative wear. As sliding takes place, the increase in temperature at the interface promotes the formation of oxides. Absence of Fe implies that, there is no material transfer from the counterface (AISI 52100 bearing steel ball). As a result, mechanical mixing of materials did not take place between the two sliding surface.

In case of $\mathrm{Al} \mathrm{6061,} \mathrm{wear} \mathrm{tracks} \mathrm{of} \mathrm{the} \mathrm{samples} \mathrm{were} \mathrm{characterized} \mathrm{by} \mathrm{surface} \mathrm{deformation} \mathrm{and} \mathrm{heavy} \mathrm{damage}$ in the form of longitudinal grooves extending parallel to the sliding direction which are clearly observed in Figure 12(a) as evidence of abrasion. This process of material removal from the surface via plastic deformation during abrasion occurs by ploughing [65]-[67]. During the ploughing process, metal is displaced to the sides of the grooves and result in the formation of ridges. These ridges become flattened and eventually fracture after repeated loading and unloading cycles. Furthermore, as pore edges represent stress concentration areas they trend to fracture with the reciprocating motion of the slider [68]. This is evident from the cracks extending from pore-edge as shown in Figure 12(c). The EDS analysis taken from the worn surface of $\mathrm{Al} 6061$ is given in Figure 12(d). It shows signs of oxidative wear as in $\mathrm{Al} \mathrm{A380M}$ alloy and no indication of material transfer from the steel counter body.

\section{Conclusions}

In the present work, the effect of porosity on tribological properties of $\mathrm{Al} \mathrm{A} 380 \mathrm{M}$ and $\mathrm{Al} 6061$ was studied. The following conclusions can be drawn: 

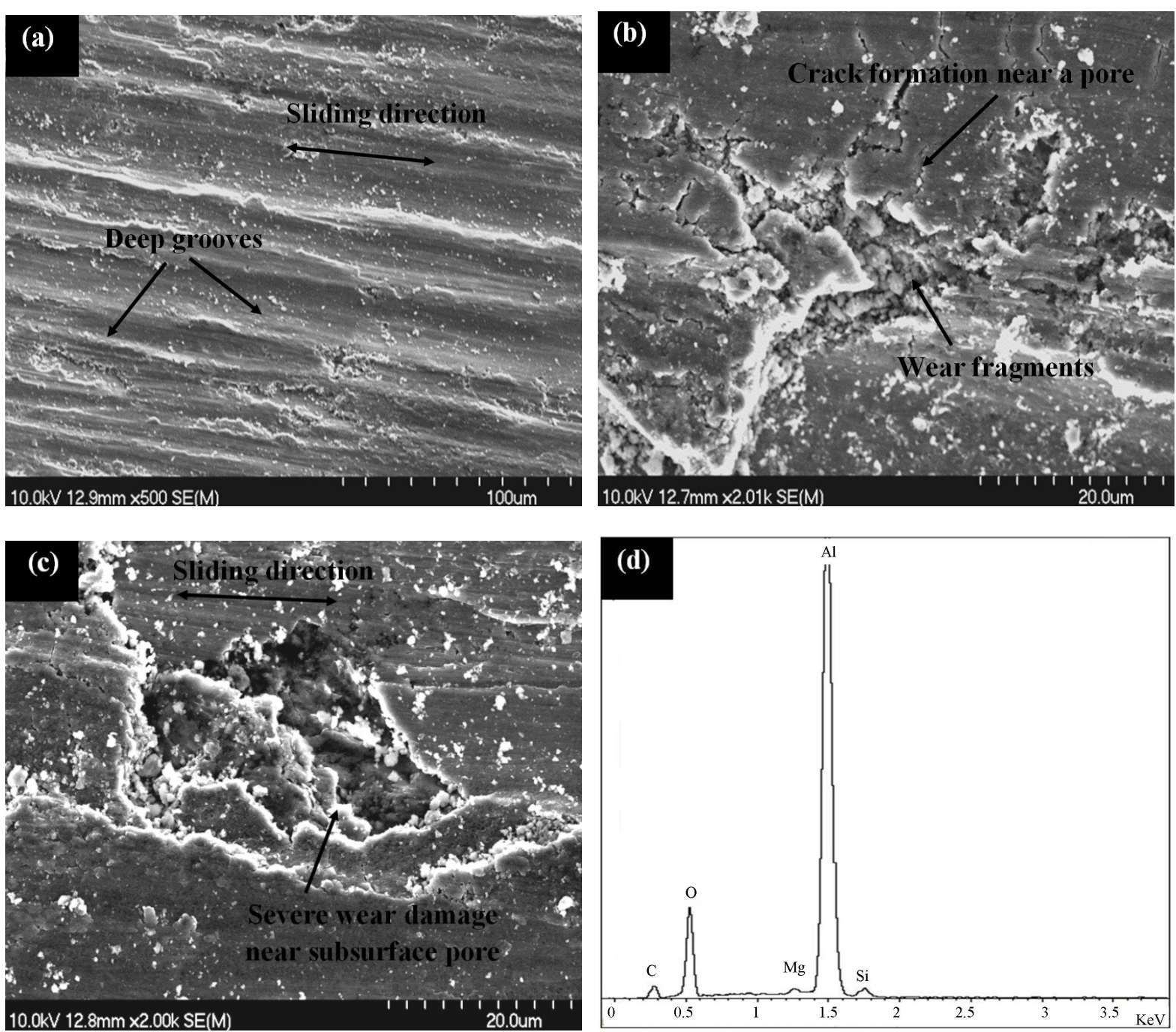

Figure 12. SEM micrographs of $\mathrm{Al} 6061$ (10.3\% porosity) wear track at $2.5 \mathrm{~N}$ load and $10 \mathrm{~Hz}$. (a) Deep grooves on the wear track; (b) Crack initiation near a pore; (c) Wear damage near a subsurface pore; (d) EDS analysis of the worn surface.

a) Wear resistance is not only a function of pore size but significantly affected by pore distribution. For a given amount of porosity and pore size uniform pore distribution results in accelerated wear.

b) Indentation hardness of porous materials leads to high maximum penetration depth and high contact depth.

c) There is an inverse relationship between the hardness and porosity content of $\mathrm{Al}$ alloys. Hardness decreases with an increase in surface porosity. For Al 6061 specimens, 20\% reduction in hardness was observed as the surface porosity increased from $3.5 \%$ to $10.3 \%$.

d) Coefficient of friction decreases considerably with increasing load but increases with increasing porosity percentage. For Al A380M alloy, coefficient of friction decreases 36\% when the applied normal load increases from $1.5 \mathrm{~N}$ to $5 \mathrm{~N}$. In case of Al 6061 alloy, at a given normal load of $3 \mathrm{~N}$, the coefficient of friction increases $40 \%$ as surface porosity increases from $3.5 \%$ to $10.3 \%$.

e) A predominance of abrasive and oxidative wear was identified on both $\mathrm{Al} \mathrm{A380M}$ and $\mathrm{Al} 6061$ alloy. In addition, delamination wear was found in $\mathrm{Al} \mathrm{A380M}$ alloy.

\section{Acknowledgements}

The authors acknowledge the financial support provided by Auto21 and Mr. Randy Cooke for his assistance in sample preparation. 


\section{References}

[1] Anand, S., Srivatsan, T.S., Wu, Y. and Lavernia, E.J. (1997) Processing, Microstructure and Fracture Behaviour of a Spray Atomized and Deposited Aluminum-Silicon Alloy. Journal of Materials Science, 32, 2835-2848. http://dx.doi.org/10.1023/A:1018668332318

[2] Zhou, J., Duszczyk, J. and Korevaar, B.M. (1991) As-Spray-Deposited Structure of an Al-20Si-5Fe Osprey Perform and Its Development during Subsequent Processing. Journal of Materials Science, 26, 5275-5291. http://dx.doi.org/10.1007/BF01143222

[3] Prasad, B.K., Venkateswarlu, K., Modi, O.P., Jha, A.K., Das, S., Dasgupta, R. and Yegneswaran, A.H. (1998) Sliding Wear Behavior of Some Al-Si Alloys: Role of Shape and Size of Si Particles and Test Conditions. Metallurgical and Materials Transactions, 29A, 2747-2752. http://dx.doi.org/10.1007/s11661-998-0315-7

[4] Shivanath, R., Sengupta, P.K. and Eyre, T.S. (1977) Wear of Aluminium-Silicon Alloys. The British Foundrymen, 70, 349-356.

[5] Yassen, R.S. and Dwarakadasa, E.S. (1983) Wear of Aluminium under Dry Sliding Conditions. Wear, 84, 375-379. http://dx.doi.org/10.1016/0043-1648(83)90277-6

[6] Min, K.H., Kang, S.P., Kim, D.G. and Kim, Y.D. (2005) Sintering Characteristic of $\mathrm{AlO}_{3}$-Reinforced 2xxx Series Al Composite Powders. Journal of Alloys Compounds, 400, 150-153. http://dx.doi.org/10.1016/j.jallcom.2005.03.070

[7] ASM and Klar, E. (1984) ASM Metal Handbook Vol. 7: Powder Metallurgy. 9th Edition, ASM International, Almere.

[8] Zhen, L. and Kang, S.B. (1997) Deformation and Fracture Behavior of Two Al-Mg-Si Alloys. Metallurgical and Materials Transactions, 28A, 1489-1497. http://dx.doi.org/10.1007/s11661-997-0211-6

[9] Clegg, A.J. and Das, A.A. (1997) The Influence of Structural Modifiers on the Refinement of the Primary Silicon in a Hypereutectic Aluminium Silicon Alloy. The British Foundryman, 70, 56-63.

[10] Molins, R., Bartout, J.D. and Beivenu, Y. (1991) Microstructural and Analytical Characterization of $\mathrm{Al}_{2} \mathrm{O}_{3} \mathrm{Composite}$ Interfaces. Materials Science and Engineering A, 135, 111-117. http://dx.doi.org/10.1016/0921-5093(91)90546-Y

[11] Nussbaum, E.D. (1997) Semi-Solid Forming of Aluminium and Magnesium. Light Metal Age, 57, 54-58.

[12] Aylor, D.M. and Moren, P.J. (1985) Corrosion Behavior of Cast Aluminium Matrix Composites in Chloride Media. Journal of the Electrochemical Society, 132, 277.

[13] Zeuner, T., Stojanov, P., Sahm, P.R., Ruppert, H. and Engels, A. (1998) Developing Trends in Disc Brake Technology for Rail Application. Materials Science and Technology, 14, 857-863. http://dx.doi.org/10.1179/mst.1998.14.9-10.857

[14] Proudhon, H., Savkova, J., Basseville, S., Guipont, V., Jeandin, M. and Cailletaud, G. (2014) Experimental and Numerical Wear Studies of Porous Reactive Plasma Sprayed Ti-6Al-4V/TiN Composite Coating. Wear, 311, 159-166. http://dx.doi.org/10.1016/j.wear.2014.01.012

[15] Zhang, L., Qu, X.H., Duan, B.H., He, X.B. and Qin, M.L. (2008) Effect of Porosity on Wear Resistance of SiC $/ \mathrm{Cu}$ Composites Prepared by Pressureless Infiltration. Transactions of Nonferrous Metals Society of China, 18, 1076-1082. http://dx.doi.org/10.1016/S1003-6326(08)60184-3

[16] Chen, Q., Li, D. and Cook, B. (2009) Is Porosity Always Detrimental to the Wear Resistance of Materials?-A Computational Study on the Effect of Porosity on Erosive Wear of TiC/Cu Composites. Wear, 267, 1153-1159. http://dx.doi.org/10.1016/j.wear.2008.12.058

[17] Simchi, A. and Danninger, H. (2004) Effects of Porosity on Delamination Wear Behaviour of Sintered Plain Iron. Powder Metallurgy, 47, 73-80. http://dx.doi.org/10.1179/003258904225015545

[18] Dubrujeaud, B., Vardavoulias, M. and Jeandin, M. (1994) The Role of Porosity in the Dry Sliding Wear of a Sintered Ferrous Alloy. Wear, 174, 155-161. http://dx.doi.org/10.1016/0043-1648(94)90097-3

[19] Li, D.Y. and Luo, Y.C. (2001) Effects of TiN Nano-Particleson Porosity and Wear Behaviour of TiC/TiNi Tribo Composite. Journal of Materials Science Letters, 20, 2249-2252.

[20] Hamid, A.A., Ghosh, P., Jain, S. and Ray, S. (2006) Influence of Particle Content and Porosity on the Wear Behaviour of Cast in Situ Al(Mn)- $\mathrm{Al}_{2} \mathrm{O}_{3}\left(\mathrm{MnO}_{2}\right)$ Composite. Wear, 260, 368-378. http://dx.doi.org/10.1016/j.wear.2005.02.120

[21] Sarikaya, O. (2005) Effect of Some Parameters on Microstructure and Hardness of Alumina Coatings Prepared by the Air Plasma Spraying Process. Surface and Coatings Technology, 190, 388-393. http://dx.doi.org/10.1016/j.surfcoat.2004.02.007

[22] Raghukiran, N. and Kumar, R. (2013) Processing and Dry Sliding Wear Performance of Spray Deposited HyperEutectic Aluminum-Silicon Alloys. Journal of Materials Processing Technology, 213, 401-410. http://dx.doi.org/10.1016/j.jmatprotec.2012.10.007

[23] Kanchanomaia, C., Saengwichian, B. and Manonukul, A. (2013) Delamination Wear of Metal Injection Moulded 316L Stainless Steel. Wear, 267, 1665-1672. http://dx.doi.org/10.1016/j.wear.2009.06.019 


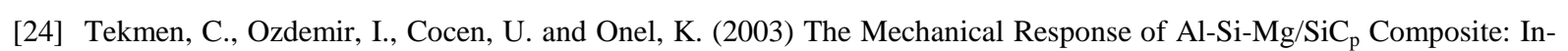
fluence of Porosity. Materials Science and Engineering: A, 360, 365-371. http://dx.doi.org/10.1016/S0921-5093(03)00461-1

[25] Danninger, H., Jangg, G., Weiss, B. and Stickler, R. (1993) Microstructure and Mechanical Properties of Sintered Iron. Part I. Basic Considerations and Review of Literature. International Journal of Powder Metallurgy, 25, 111-117.

[26] Bergmark, A., Alzati, L. and Persson, U. (2002) Crack Initiation and Crack Propagation in Copper Powder Mixed PM Steel. Powder Metallurgy Progress, 2, 222-230.

[27] Gerard, D.A. and Koss, D.A. (1990) Low Cycle Fatigue Crack Initiation: Modeling the Effect of Porosity. International Journal of Powder Metallurgy, 26, 337-343.

[28] Sahin. Y. (2003) Preparation and Some Properties of SiC Particle Reinforced Aluminium Alloy Composites. Materials and Design, 24, 671-679. http://dx.doi.org/10.1016/S0261-3069(03)00156-0

[29] Sahin, Y. and Acilar, M. (2003) Production and Properties of $\mathrm{SiC}_{\mathrm{p}}$-Reinforced Aluminium Alloy Composites. Composites Part A: Applied Science and Manufacturing, 34, 709-718. http://dx.doi.org/10.1016/S1359-835X(03)00142-8

[30] Yih, P. and Chung, D.D.L. (1997) Titanium Diboride Copper-Matrix Composites. Journal of Materials Science, 32, 1703-1709. http://dx.doi.org/10.1023/A:1018515714687

[31] Ray, S., Fishman, S.G. and Dhingra, A.K. (1988) Porosity in Foundry Composites Prepared by Vortex Method. Proceedings of Cast Reinforced Metal Composites, Chicago, 24-30 September 1988, 77-86.

[32] Mathew, B.A. and Mastromatteo, R. (2002) Metal Injection Moulding for Automotive Applications. Metal Powder Report, 57, 20-23. http://dx.doi.org/10.1016/S0026-0657(02)85078-0

[33] Bocchini, G.F. (1986) Influence of Porosity on the Characteristics of Sintered Materials. International Journal of Powder Metallurgy, 22, 185-188.

[34] Klar, E. and Samal, P.K. (1994) Powder Metallurgy Stainless Steels. In: Eisen, W.B. and German, R.M., Eds., ASM Handbook, Powder Metal Technologies and Applications, Vol. 7, ASM International, Ohio, 474-482.

[35] Hardin, R.A. and Beckermann, C. (2007) Effect of Porosity on the Stiffness of Cast Steel. Metallurgical, and Materials Transactions A, 12, 2992-3006. http://dx.doi.org/10.1007/s11661-007-9390-4

[36] Deshpande, P. and Lin, R. (2006) Wear Resistance of WC Particle Reinforced Copper Matrix Composites and the Effect of Porosity. Materials Science and Engineering A, 418, 137-145. http://dx.doi.org/10.1016/j.msea.2005.11.036

[37] Suh, N.P. (1977) An Overview of the Delamination Theory of Wear. Wear, 44, 1-16. http://dx.doi.org/10.1016/0043-1648(77)90081-3

[38] Vardavoulias, M., Jouanny-Tresy, C. and Jeandin, M. (1993) Sliding-Wear Behaviour of Ceramic Particle-Reinforced High-Speed Steel Obtained by Powder Metallurgy. Wear, 165, 141-149. http://dx.doi.org/10.1016/0043-1648(93)90329-K

[39] Gui, M., Kang, S.B. and Lee, J.M. (2000) Influence of Porosity on Dry Sliding Wear Behaviour in Spray Deposited Al-6Cu-Mn/SiC $\mathrm{p}_{\mathrm{p}}$ Composite. Materials Science and Engineering A, 293, 146-156. http://dx.doi.org/10.1016/S0921-5093(00)01052-2

[40] Bertilsson, I., Karlsson, B. and Wasen, J. (1994) Fatigue Properties of Sintered Steels. International Conference on Powder Metallurgy and Particulate Materials, Vol. 16, Toronto, May 8-11, 1984, 19-32.

[41] Oliver, W.C. and Pharr, G.M. (1992) Improved Technique for Determining Hardness and Elastic Modulus Using Load and Displacement Sensing Indentation Experiments. Journal of Materials Research, 74, 1564-1580. http://dx.doi.org/10.1557/JMR.1992.1564

[42] Fleck, N.A., Otoyo, H. and Needleman, A. (1992) Indentation on Porous Solids. International Journal of Solids and Structures, 29, 1613-1636. http://dx.doi.org/10.1016/0020-7683(92)90012-I

[43] Jang, B.K. and Matsubara, H. (2005) Influence of Porosity on Hardness and Young's Modulus of Nanoporous EBPVD TBCs by Nanoindentation. Materials Letters, 59, 3462-3466. http://dx.doi.org/10.1016/j.matlet.2005.06.014

[44] Chen, X., Xiang, Y. and Vlassak, H.J. (2006) Novel Technique for Measuring the Mechanical Properties of Porous Materials by Nanoindentation. Journal of Materials Research, 21, 715-724. http://dx.doi.org/10.1557/jmr.2006.0088

[45] Ling, Z., Wang, X. and Ma, J. (2008) The Response of Porous $\mathrm{Al}_{2} \mathrm{O}_{3}$ Probed to Nanoindentation. Materials Science and Engineering: A, 483-484, 285-288. http://dx.doi.org/10.1016/j.msea.2006.10.195

[46] Dwivedi, D.K. (2010) Adhesive Wear Behaviour of Cast Aluminium-Silicon Alloys: Overview. Materials and Design, 31, 2517-2531. http://dx.doi.org/10.1016/j.matdes.2009.11.038

[47] Elmadagli, M., Perry, T. and Alpas, A.T. (2007) A Parametric Study of the Relationship between Microstructure and Wear Resistance of Al-Si Alloys. Wear, 262, 79-92. http://dx.doi.org/10.1016/j.wear.2006.03.043

[48] Singla, M., Singh, L. and Chawla, V. (2009) Study of Wear Properties of Al-SiC Composites. Journal of Minerals and 
Materials Characterization and Engineering, 8, 813-819.

[49] Wei, M.X., Chen, K.M., Wang, S.Q. and Cui, X.H. (2011) Analysis for Wear Behaviors of Oxidative Wear. Tribology Letters, 42, 1-7. http://dx.doi.org/10.1007/s11249-010-9741-y

[50] Kumar, S. and Balasubramanian, V. (2010) Effect of Reinforcement Size and Volume Fraction on the Abrasive Wear Behaviour of AA7075 Al/SiC $\mathrm{p}_{\mathrm{p}}$ /M Composites-A Statistical Analysis. Tribology International, 43, 414-422. http://Dx.doi.org/10.1016/j.triboint.2009.07.003

[51] Corrochanoa, J., Walker, J.C., Lieblich, M., Ibanez, J. and Rainforth, W.M. (2011) Dry Sliding Wear Behaviour of Powder Metallurgy Al-Mg-Si Alloy-MoSi ${ }_{2}$ Composites and the Relationship with the Microstructure. Wear, 270, 658665. http://dx.doi.org/10.1016/j.wear.2011.01.029

[52] Bermudez, M.D., Martinez-Nicolas, G., Carrion, F.J., Martinez-Mateo, I., Rodriguez, J.A. and Herrera, E.J. (2001) Dry and Lubricated Wear Resistance of Mechanically-Alloyed Aluminium-Base Sintered Composites. Wear, 248, 178-186. http://dx.doi.org/10.1016/S0043-1648(00)00553-6

[53] Yasmin, T., Khalid, A.A. and Haque, M.M. (2004) Tribological (Wear) Properties of Aluminum-Silicon Eutectic Base Alloy under Dry Sliding Condition. Journal of Materials Processing Technology, 153-154, 833-838. http://dx.doi.org/10.1016/j.jmatprotec.2004.04.147

[54] Hamn, M., Talib, I.A. and Daud, A.R. (1996) Effect of Element Additions on Wear Property of Eutectic Aluminium-Silicon Alloys. Wear, 194, 54-59. http://dx.doi.org/10.1016/0043-1648(95)06707-8

[55] Casellas, D., Beltran, A., Prado, J.M., Larson, A. and Romero, A. (2004) Microstructural Effects on the Dry Wear Resistance of Powder Metallurgy Al-Si Alloys. Wear, 257, 730-739. http://dx.doi.org/10.1016/j.wear.2004.03.011

[56] Sharifi, E.M. and Karimzadeh, F. (2011) Wear Behavior of Aluminum Matrix Hybrid Nanocomposites Fabricated by Powder Metallurgy. Wear, 271, 1072-1079. http://dx.doi.org/10.1016/j.wear.2011.05.015

[57] Rahimian, M., Parvin, N. and Ehsani, N. (2011) The Effect of Production Parameters on Microstructure and Wear Resistance of Powder Metallurgy Al- $\mathrm{Al}_{2} \mathrm{O}_{3}$ Composite. Materials and Design, 32, 1031-1038. http://dx.doi.org/10.1016/j.matdes.2010.07.016

[58] Ravindran, P., Manisekar, K., Rathika, P. and Narayanasamy, P. (2013) Tribological Properties of Powder Metallurgy Processed Aluminium Self Lubricating Hybrid Composites with SiC Additions. Materials and Design, 45, 561-570. http://dx.doi.org/10.1016/j.matdes.2012.09.015

[59] Hamid, A A., Ghosh, P.K., Jain, S.C. and Ray, S. (2008) The Influence of Porosity and Particles Content on Dry Sliding Wear of Cast in Situ Al(Ti)- $\mathrm{Al}_{2} \mathrm{O}_{3}\left(\mathrm{TiO}_{2}\right)$ Composite. Wear, 265, 14-26. http://dx.doi.org/10.1016/j.wear.2007.08.018

[60] Y1lmaz, O. and Buytoz, S. (2001) Abrasive Wear of $\mathrm{Al}_{2} \mathrm{O}_{3}$-Reinforced Aluminium-Based MMCs. Composites Science and Technology, 61, 2381-2392. http://dx.doi.org/10.1016/S0266-3538(01)00131-2

[61] Bhushan, B. (2002) Introduction to Tribology. John Wiley \& Sons, Inc., New York.

[62] AL-Samari, R.A., Haftirman, Ahmad, K.R. and AL-Douri, Y. (2013) The Tribological Behavior of Hypo and Hyper Eutectic Al-Si Alloys under Dry Sliding Condition. International Journal of Mechanical and Production Engineering Research and Development (IJMPERD), 3, 111-124.

[63] Yalcin, B. (2009) Effect of Porosity on the Mechanical Properties and Wear Performance of 2\% Copper Reinforced Sintered Steel Used in Shock Absorber Piston Production. Journal of Materials Science and Technology, 25, 577-582.

[64] Prasada Rao, A.K., Das, K., Murty, B.S. and Chakraborty, M. (2008) Microstructure and the Wear Mechanism of Grain-Refined Aluminium during Dry Sliding against Steel Disc. Wear, 264, 638-647. http://dx.doi.org/10.1016/j.wear.2007.05.010

[65] Gyimah, G.K., Chen, D. and Huang, P. (2008) Dry Sliding Studies of Porosity on Sintered Cu-Based Brake Materials. Transaction on Control and Mechanical Systems, 2, 219-224.

[66] Alshmri, F., Atkinson, H.V., Hainsworth, S.V., Haidon, C. and Lawes, S.D.A. (2014) Dry Sliding Wear of Aluminium-High Silicon Hypereutectic Alloys. Wear, 313, 106-116. http://dx.doi.org/10.1016/j.wear.2014.02.010

[67] Deya, S.K., Perry, T.A. and Alpas, A.T. (2009) Micromechanisms of Low Load Wear in an Al-18.5\% Si Alloy. Wear, 267, 515-524. http://dx.doi.org/10.1016/j.wear.2008.11.011

[68] Islam, M.A. and Farhat, Z.N. (2011) The Influence of Porosity and Hot Isostatic Pressing Treatment on Wear Characteristics of Cast and P/M Aluminium Alloys. Wear, 271, 1594-1601. http://dx.doi.org/10.1016/j.wear.2011.01.037 
Scientific Research Publishing (SCIRP) is one of the largest Open Access journal publishers. It is currently publishing more than 200 open access, online, peer-reviewed journals covering a wide range of academic disciplines. SCIRP serves the worldwide academic communities and contributes to the progress and application of science with its publication.

Other selected journals from SCIRP are listed as below. Submit your manuscript to us via either submit@scirp.org or Online Submission Portal.
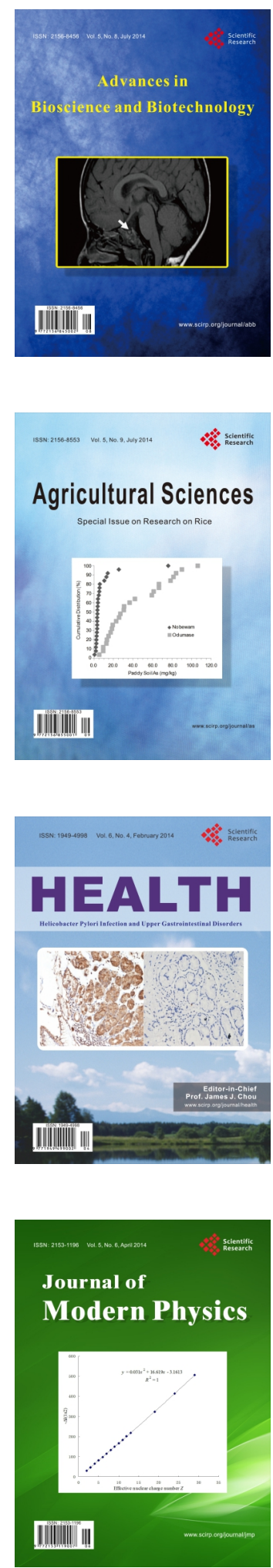
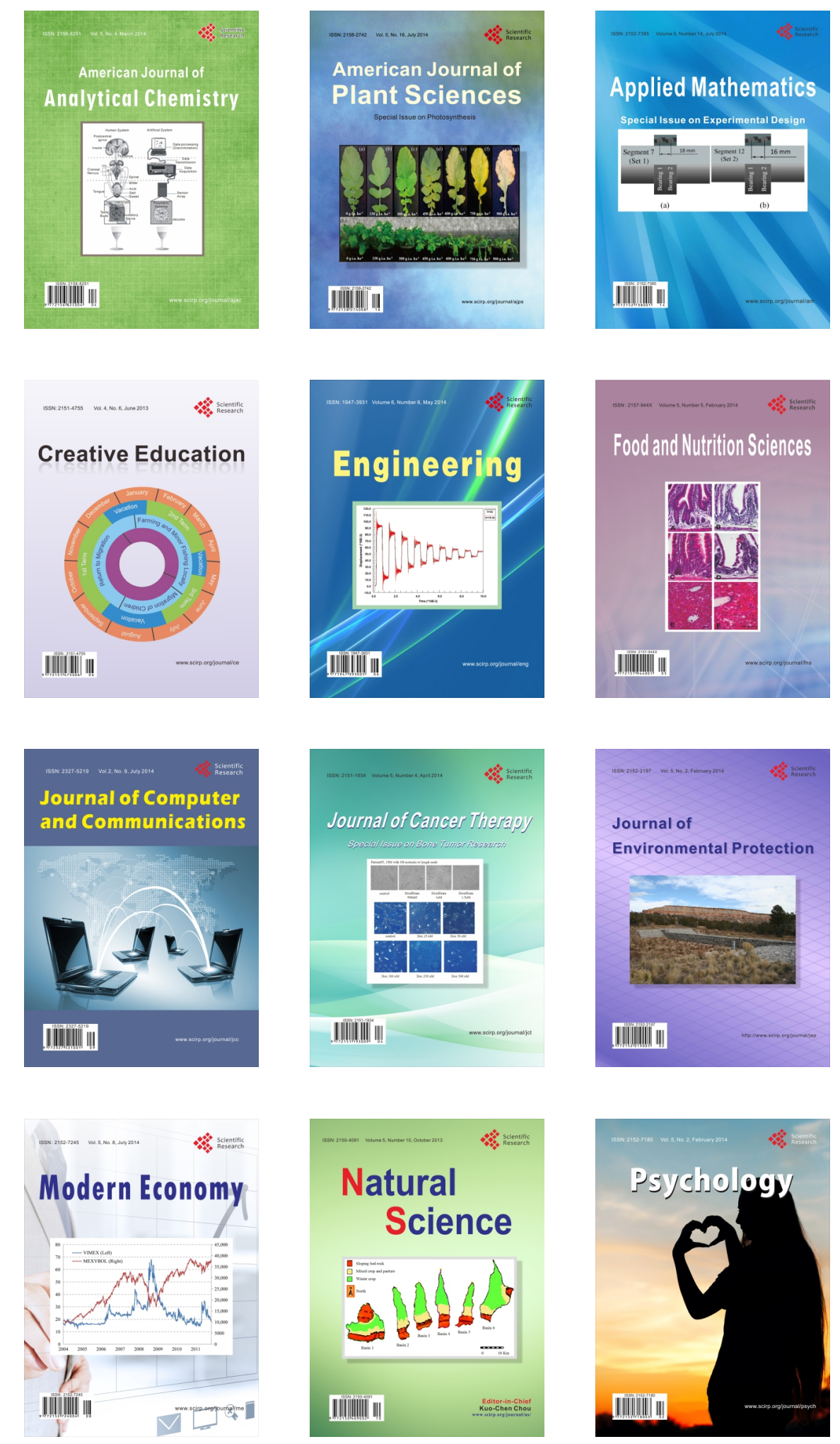